\title{
Evaluation of the shelf-life of blackberry pulp fortified with $p$ hysiologically active compounds
}

\author{
Evaluación de la vida útil de la pulpa de mora enriquecida con compuestos fisiológicamente activos \\ María Alejandra Restrepo ${ }^{1}$, Julio Cesar Luna-Ramírez², Victor Dumar Quintero-Castaño ${ }^{3 *}$ \\ IFood Engineering, marestrepog@uqvirtual.edu.co, ORCID: 0000-0002-8887-8760,Universidad del Quindío, Armenia, Colombia. \\ 2Ph.D. jcluna@uniquindio.edu.co, ORCID: 0000-0001-8430-7293, Universidad del Quindio, Armenia, Colombia. \\ 3*Ph.D. victordumar@uniquindio.edu.co,ORDID: 0000-0002-0252-7514, Universidad del Quindío, Armenia, Colombia.
}

How to cite: M.A. Restrepo, J.C. Luna, Ramirez, V. Castaño-Quintero, "Evaluation of the shelf-life of blackberry pulp fortified with physiologically active compounds”. Respuestas, vol. 24, no. 2, pp. 16-25, 2019.

Received on September 27, 2018; Approved on December 03, 2018

\begin{tabular}{ll}
\hline ABSTRACT \\
\hline Keywords: & $\begin{array}{l}\text { The shelf-life of a pasteurized blackberry juice with added calcium and vitamin } \mathrm{C} \text { was evaluated in the } \\
\text { present work. The product underwent physicochemical, microbiological, and sensory characterization at } 25,\end{array}$ \\
Pulp, & 35, and $45^{\circ} \mathrm{C}$ for 30 days at $80 \%$ relative humidity. An analysis of variance was performed to determine the \\
Blackberry, & variable most affected during storage. The results showed that mesophilic microorganisms were detected \\
Shelf-life. & on day 21 of storage at $15^{\circ} \mathrm{C}$, at day 18 at $25^{\circ} \mathrm{C}$, and at day 11 at $35^{\circ} \mathrm{C}$. Integrated kinetic and Arrhenius \\
& mathematical models were obtained for the physicochemical variables $\mathrm{L}^{*}, \mathrm{a} *, \mathrm{~b} *$, brix, pH, and viscosity. \\
& The kinetic models of the sensory behavior of the blackberry pulp stored at $25{ }^{\circ} \mathrm{C}$ were obtained. It was \\
& possible to sensorily determine that the product was rejected on average for all descriptors at 12 days.
\end{tabular}

\section{RESUMEN}

Palabras clave:

Pulpa,

Mora,

Vida útil.
La vida útil de un jugo de mora pasteurizado adicionado con calcio y vitamina $\mathrm{C}$ fue evaluado en el presente trabajo. El producto fue caracterizado fisicoquímica, microbiológica y sensorialmente a 25,35 y $45{ }^{\circ} \mathrm{C}$ durante 30 días a $80 \%$ de humedad relativa. Se realizó un análisis de varianza para determinar la variable más afectada en el almacenamiento. Los resultados mostraron que los microorganismos mesófilos se detectaron el día 21 de almacenamiento a $15{ }^{\circ} \mathrm{C}$, el día 18 a $25^{\circ} \mathrm{C}$ y el día 11 a $35^{\circ} \mathrm{C}$. Los modelos matemáticos integrados cinéticos y Arrhenius se obtuvieron para las variables fisicoquímicas $\mathrm{L}^{*}, \mathrm{a}^{*}, \mathrm{~b} *$, brix, $\mathrm{pH}$ y viscosidad. Los modelos cinéticos del comportamiento sensorial de la pulpa almacenada a $25{ }^{\circ} \mathrm{C}$ fueron obtenidos. Se pudo determinar sensorialmente que el producto fue rechazado en promedio para todos los descriptores de 12 días.

\section{Introduction}

Processed products obtained from blackberry have been commercially exploited, to the point that most of the blackberry produced in Colombia is purchased by companies, like Postobon ${ }^{\circledR}$, Compañía Nacional de Chocolates ${ }^{\circledR}$, Casa Luker ${ }^{\circledR}$, Agrofood $^{\circledR}$, Pascol $^{\circledR}$, and Alpina ${ }^{\circledR}$ [1]. It is clear that at present, according to reports from the Colombian Ministry of Agriculture in its platform "www.siembra.gov.co" no research, development and innovation work related to the agroindustrial exploitation of the blackberry is observed, especially in the Andean region, which has the highest production of this fruit [2].

Blackberry is a perishable product that can last in storage from 5 days in fresh state to 1 month in frozen state. This implies that there may be great loss due to the lack of existing technical capacity to preserve the organoleptic, microbiological, and

*Corresponding author.

E-mail address: victordumar@uniquindio.edu.co (Victor Dumar Quintero-Castaño)

(c) $(1) \Theta$ Peer review is the responsibility of the Universidad Francisco de Paula Santander

(c) This is an article under the license CC BY-ND (http://creativecommons.org/licenses/by-nc-nd/4.0). 
nutritional characteristics of blackberry [3]. The Siembra platform by the Ministry of Agriculture in the area of harvest, post-harvest, and transformation management for the blackberry chain shows a demand in bio-prospection to develop agroindustry and transform this type of product. Development of new products with high added value for national and international markets is of interest for researches. Poor participation by national players is noted in the research on transformation alternatives for food, health, and industry compared to the participation by international players in this same chain. On this platform, it can be observed that contributions by national entities towards improving the agroindustrialization of the blackberry has been quite low. It can also be perceived that most efforts made in the chain have been in agricultural areas, like management of the production system, sanitary and phytosanitary management, and planting material and genetic improvement; the area of harvest management, postharvest and transformation would be fourth in importance according to the projects presented and the results published nationally [2].

Concern arises because blackberry producers and processors are not being supplied with knowledge so that they can obtain processed products with greater added value and with immersed scientific knowledge to obtain better economic benefit without involving intermediaries, who earn the greatest financial profit of selling the product to specialized markets. This implies that it is necessary for regional research, development, and innovation participants to become more involved in the generation of knowledge and interaction with the productive sector to secure better products, techniques, and production processes of transformation and generation of added value in the blackberry chain.

Blackberry has excellent nutritional characteristics, providing a substantial amount of water, carbohydrates, and fiber, but its most important contribution is in the content of anthocyanins, given that this group of molecules has been reported as antioxidants for humans, generating much interest from the scientific point of view.
One way to take advantage of these anthocyanins is to manufacture food products based on blackberries, high fruit content, and without the addition of water, caloric sweeteners and artificial preservatives to obtain foods that benefit the health of consumers; these foods are also called functional foods.

One of these products is fruit pulp, which is used as a base to prepare juices, nectars, compotes, ice cream, and pastries, among others. According to the Colombian technical standard 5468 "juices, nectars, purées (pulps), and fruit concentrates" to produce fruit pulp, it is necessary to extract the liquid and edible part of the fruit by mechanical means and without the addition of water; additionally, all the solids of the pulp must be contributed by the fruit. Furthermore, resolution 333 of 2011 by the Ministry of Social Protection "by which the technical regulation is established on the requirements of labeling or nutritional labeling that must be met for food packaged for human consumption" approves and regulates the addition of bioactive chemical compounds to fortify pulps, such as vitamins and minerals. There is no information related to the mass production of these products and, therefore, no information is available on their deterioration kinetics.

Empirical mathematical models related to the kinetics of degradation of physicochemical, microbiological, and sensory properties are widely used in the food industry because an approximation can be made about the behavior of a given food matrix during its storage to establish the shelf-life of certain foods [4]. The storage temperature control is another key variable to determine the kinetics of deterioration of food, which is why the Arrhenius theoretical model allows a better approach towards understanding the degradation reactions that occur within a food system because it involves changes in storage temperature with the equilibrium constants of the reactions involved [5].

The main objective of this work was to model mathematically, by means of empirical equations, the degradation during its period of storage of a formulation of a food product derived from 
blackberry with functional characteristics and determine the shelf-life.

\section{Materials and Methods}

The blackberries were purchased at the wholesale supply center for fruits and vegetables in the city of Armenia, Quindío, Colombia in a state of maturation between 4 and 5, which were harvested in the population of Salento, Quindío.

The plant material was taken to the pilot plant in University of Quindío, located in Armenia, Quindío, Colombia where these were washed, selected, blanched, and homogenized in a conventional blender. The homogenate was passed through a 100 $\mu \mathrm{m}$ pore size mesh to remove large residues, then portioned into $200 \mathrm{~g}$ portions and frozen for later use [6].

Subsequently, the portions were thawed and pectinase enzyme was added to reduce their viscosity; Xanthan gums and carboxymethyl cellulose to stabilize the pulp; sodium citrate as acidity regulator; sucralose as a non-caloric sweetener; and calcium citrate and ascorbic acid as physiologically active components [7]. The percentages of each of the ingredients are reported in Table 1. Thereafter, the pulp obtained was subjected to pasteurization for $30 \mathrm{~s}$ at $80{ }^{\circ} \mathrm{C}$ to, then, perform the physicochemical and sensory analyses of its deterioration. This formulation was made based on the Colombian technical standard 5468 "juices, nectars, purées (pulps), and fruit concentrates" and Resolution 333 of 2011 by the Ministry of Social Protection "by which the technical regulation is established on the requirements of labeling or nutritional labeling that must be met for food packaged for human consumption”.

Table I. Composition of the blackberry pulp formulation fortified with calcium and vitamin $\mathrm{C}$.

\begin{tabular}{|l|l|}
\hline Component & Percentage \% \\
\hline Pulp & 98.716 \\
\hline Enzime ( Pectinase) & 0.076 \\
\hline Gum (CMC) & 0.05 \\
\hline Sodium citrate & 0.25 \\
\hline $\begin{array}{l}\text { Calcium (20\% VDR) } \\
\text { Calcium citrate }\end{array}$ & 0.41 \\
\hline $\begin{array}{l}\text { Vitamin C (20\% VDR) } \\
\text { Ascorbic acid }\end{array}$ & 0.004 \\
\hline Sucralose (BPM) & 0.5 \\
\hline TOTAL & 100 \\
\hline
\end{tabular}

\section{Evaluation of deterioration kinetics}

The functional pulp obtained was stored at three temperatures $\left(15,25\right.$ and $\left.35{ }^{\circ} \mathrm{C}\right)$ and at constant relative humidity of $80 \%$ for 20 days. Every three days, starting from day zero, the physicochemical characterization was carried out by analyzing the $\mathrm{pH}$ variables via the potentiometric method, using a glass electrode, according to the AOAC 981.12 method viscosity was measured with a rotational viscometer (Selecta, reference ST 2010) at room temperature; color was measured with a Minolta CR 10 spectrophotometer, with D65 illuminant and $10^{\circ}$ standard observer; the ICD-L* $a^{*} b^{*}$ coordinates were determined from the reflection spectra of the samples, where the luminance component $(\mathrm{L} *)$ varies between 0 and 100 and the $\mathrm{a}^{*}$ component (green-red axis) and $b^{*}$ component (blue-yellow axis) can be between +127 and -128 [8]; soluble solids were determined with a THERMO table refractometer, scale from 0 to $85{ }^{\circ} \mathrm{Brix}$, following the AOAC 932.12 method. Microbiological analysis was performed on the pulp by determining mesophilic and total coliform microorganisms. The mesophilic microorganism count was performed by serial dilutions of fruit pulp up to $10-3$ in peptone water and coliform counts were performed by using the most-probable number technique [9].

Prior to the physicochemical analyses, a sensory analysis was performed on samples stored at 25 ${ }^{\circ} \mathrm{C}$. The samples were introduced at random and simultaneously during the storage period to the previously semi-drilled judges, who were 10 students from the Food Engineering Program at Universidad del Quindío and who had previous knowledge about sensory analysis. The descriptors of flavor, color, aroma, texture, and general appearance were evaluated on a scale of 1 to 5 where 1 is very unpleasant and 5 I like a lot, admitting that values below 3 are unacceptable parameters for consumption, that is, values rejecting the quality parameter. An analysis of variance was performed to determine the variable most affected during storage in order to model the deterioration kinetics with a 95\% confidence level [10], [11]. 
The mathematical modeling that describes the degradation of the blackberry pulp was made based on the integration of the kinetics and Arrhenius (1 to 3) proposed by [4].

$$
\begin{gathered}
Q=Q o-k t \\
Q=Q o e^{-k t} \\
k=k o e^{-E a / R T} \\
Q=Q o-k o t e^{-E a / R T} \\
Q=Q o e^{-k o t e^{-E a / R T}}
\end{gathered}
$$

Source: [4]

Where:

$\mathrm{Q}=$ value of the physicochemical variable evaluated at time $\mathrm{t}$

Qo $=$ Value of the physicochemical variable evaluated at the initial time.

$\mathrm{k}=$ equilibrium constant of the deterioration reaction ko $=$ Preexponential constant.

$\mathrm{T}=$ Time in days of storage.

$\mathrm{Ea}=$ Activation energy of the deterioration reaction

$\mathrm{T}=$ temperature in Kelvin.

$\mathrm{R}=$ Gas constant.

The results were proccesed with the Statgraphisc Centurion 15.2 software.

\section{Results and Discussion}

The final time of the analyses was determined by the appearance of mesophilic microorganisms, which for samples stored at $15{ }^{\circ} \mathrm{C}$ were detected at 21 days; for samples stored at $25{ }^{\circ} \mathrm{C}$, these were observed at 18 days; and for samples storage at $35^{\circ} \mathrm{C}$, the microorganisms were detected at 11 days. Therefore, on these days the sensory and physicochemical analyses were not conducted and, therefore, the end point of the kinetics was taken the day before detecting the mesophilic microorganisms, observing that at $15^{\circ} \mathrm{C}$ the analyses were carried out until day 18; at $25^{\circ} \mathrm{C}$ until day 15 ; and at $15{ }^{\circ} \mathrm{C}$ until day 10 . Total aerobic microorganisms were not detected at any stage of kinetics.
Similar research on the shelf-life of canteloupe reported the occurrence of mesophilic microorganisms at 7 days of storage at room temperature [12]. Other researchers reported the occurrence of mesophilic microorganisms in carrot juice treated with ultrasound at 20 days of storage [13].

Tables 2, 3, and 4 show the zero order and first order kinetic equations for the physicochemical variables evaluated at the three working temperatures. The equations were obtained by analyzing the product 20 days for samples stored at $15^{\circ} \mathrm{C}, 16$ days for those stored at $25^{\circ} \mathrm{C}$, and 10 days for $35^{\circ} \mathrm{C}$. Completion times were determined when the product is totally degraded physicochemically and microbiologically.

It can be observed in the kinetic equations obtained and according to the results of the analysis of variance that the parameter most influenced during the storage is that of the $\mathrm{a}^{*}$ chromatic axis, which in all the working temperatures and the kinetic models calculated obtained a p-value of 0.0000 . This indicates statistical significance in its variability during the product's storage time. Given that all the kinetic equations calculated for this variable have a positive slope, this indicates that the violet-purple color of the blackberries is lost and becomes increasingly red, which is reflected in the increase of the $a^{*}$ parameter with the weather. This variability was also detected in the sensory analysis performed because the kinetic equation for the aroma descriptor also had a high significance (Table 7). This degradation is mainly due to the gradual decomposition that anthocyanins undergo due to thermal exposure, light of the medium, or $\mathrm{pH}$ changes [14] - [16]. In other works, mathematical models for the degradation of mango fruit have been proposed [6], where the authors propose nonlinear mathematical models to describe the behavior of mango during storage.

In terms of viscosity, it was observed that in spite of the stabilization process carried out on the blackberry pulp, the water tends to be strongly retained in the polysaccharides of the pulp matrix generating increased viscosity with increased time [16] [18]. 
This indicates that the initial formulation has failed and that further studies may be needed to improve the stabilization of the product for the viscosity to remain constant over time.

Previous studies have reported kinetic empirical models to describe food degradation. For example, some authors proposed zero-order and first-order empirical kinetic equations to determine the shelflife of bananas treated with soy lecithin [19]; other authors empirically modeled the physicochemical behavior of compotes based on various fruits to know their useful life [20].

Table 5 presents the empirical equations of the Arrhenius model. It can be observed that the only variable that does not follow this model is $a^{*}$ because its slope is positive and, therefore, has a positive correlation coefficient. One of the main features of the Arrhenius model is that its slope must be negative given that the temperature inverse must always be inversely proportional to the logarithm of the equilibrium constant of the reaction. This could lead to the lack of color homogeneity of the pulps worked, which leads to not all the pulps having the same color at the time of the analysis and, therefore, their changes during storage could be different.

The other variables behaved close to the theoretical model proposed by Arrhenius because their correlation coefficients were close to -1 , indicating an inverse linear variability between the temperature inverse and the logarithm of their equilibrium constants. Other authors have reported results of Arrhenius mathematical models applied to the degradation of food systems, like formulations for children [20], patulin in applesauce [21], acerola pulp [14], and orange juice [15].

Table 6 shows the coefficients of the empirical equations obtained by integrating the kinetic equations with those by Arrhenius (3). With these equations, the variability of each of the parameters analyzed can be mathematically related by linkinthe storage time and the storage temperature to the desired quality factor of the product.

Knowing these two parameters can predict the behavior of each of the variables analyzed and can, therefore, be an approximation to determine the useful life of the product.

Table II. Kinetic equations of deterioration of blackberry pulp at $15^{\circ} \mathrm{C}$.

\begin{tabular}{|c|c|c|c|c|c|c|}
\hline & \multicolumn{3}{|l|}{ Zero order } & \multicolumn{3}{|l|}{ First order } \\
\hline & Equation & $\mathrm{R}$ & p value & Equation & $\mathrm{R}$ & p value \\
\hline $\mathrm{L}^{*}$ & $L^{*}=30.9857+0.0952381^{*}$ Day & 0.611942 & 0.0032 & $\log L^{*}=1.49135+0.00127547^{*}$ Day & 0.606521 & 0.0036 \\
\hline$a^{*}$ & $a^{*}=13.6881-0.192857^{*}$ Day & -0.802404 & 0.0000 & $\log \mathrm{a}^{*}=1.13887-0.00718728^{*}$ Day & -0.802234 & 0.0000 \\
\hline $\mathrm{b}^{*}$ & $b^{*}=8.58452-0.0384921^{*}$ Day & -0.164707 & 0.4756 & Log $b^{*}=0.920609-0.00103555^{*}$ Day & -0.107255 & 0.6435 \\
\hline $\mathrm{pH}$ & $\mathrm{pH}=4.36893+0.0115476^{*}$ Day & 0.632453 & 0.0021 & $\log \mathrm{pH}=0.640207+0.0011384 *$ Day & 0.632678 & 0.0021 \\
\hline Brix & Brix $=8.37262-0.0107143 *$ Day & -0.190235 & 0.4088 & Log Brix $=0.921998-0.000502043^{*}$ Day & -0.173851 & 0.4510 \\
\hline $\mathrm{U}$ & $\mathrm{u}=402.655+10.5992 *$ Day & 0.72546 & 0.0002 & $\log u=2.59443+0.0105167$ *Day & 0.711008 & 0.0003 \\
\hline
\end{tabular}

Table III. Kinetic equations of deterioration of blackberry pulp at $25^{\circ} \mathrm{C}$.

\begin{tabular}{|c|c|c|c|c|c|c|}
\hline & \multicolumn{3}{|l|}{ Zero order } & \multicolumn{3}{|l|}{ First order } \\
\hline & Equation & $\mathrm{R}$ & $p$ value & Equation & $\mathrm{R}$ & $p$ value \\
\hline$L^{*}$ & $L^{*}=29.4892+0.89018^{*}$ Day & 0.475516 & 0.0732 & $\log L^{*}=1.53249+0.0027165^{*}$ Day & 0.842599 & 0.0001 \\
\hline $\mathrm{a}^{*}$ & $a^{*}=13.7467+0.273333^{*}$ Day & 0.914176 & 0.0000 & $\log a^{*}=1.13874+0.00781667^{*}$ Day & 0.912417 & 0.0000 \\
\hline $\mathrm{b}^{*}$ & $b^{*}=8.7434-0.0277778^{*}$ Day & -0.35540 & 0.1936 & Log $b^{*}=0.940896-0.00134492^{*}$ Day & -0.340591 & 0.2142 \\
\hline $\mathrm{pH}$ & $\mathrm{pH}=4.45+0.0121111 *$ Day & 0.761512 & 0.0010 & $\log \mathrm{pH}=0.648336+0.00116834^{*}$ Day & 0.761168 & 0.0010 \\
\hline Brix & Brix $=6.42+0.0366667^{*}$ Day & 0.260823 & 0.3478 & Log Brix $=0.804143+0.00267469 *$ Day & 0.3385 & 0.3385 \\
\hline $\mathrm{U}$ & $u=671.467+37.8889 *$ Day & 0.836354 & 0.0001 & $\log u=2.81413+0.0211285^{*}$ Day & 0.7979 & 0.0004 \\
\hline
\end{tabular}

Table IV. Kinetic equations of deterioration of blackberry pulp at $35^{\circ} \mathrm{C}$

\begin{tabular}{|c|c|c|c|c|c|c|}
\hline & \multicolumn{3}{|l|}{ Zero order } & \multicolumn{3}{|l|}{ First order } \\
\hline & Equation & $\mathrm{R}$ & $p$ value & Equation & $\mathrm{R}$ & $p$ value \\
\hline $\mathrm{L}^{*}$ & $L^{*}=31.9619+0.113968^{*}$ Day & 0.610526 & 0.0071 & $\log L^{*}=1.50474+0.00148981^{*}$ Day & 0.605653 & 0.0077 \\
\hline$a^{*}$ & $a^{*}=13.2857-0.444762^{*}$ Day & -0.976074 & 0.0000 & $\log a^{*}=1.13507-0.0199557^{*}$ Day & -0.972451 & 0.0000 \\
\hline $\mathrm{b}^{*}$ & $b^{*}=7.6254+0.0292063^{*}$ Day & 0.345092 & 0.1608 & $\log b^{*}=0.882183+0.00156047^{*}$ Day & 0.32848 & 0.1832 \\
\hline $\mathrm{pH}$ & $\mathrm{pH}=4.2877+0.0195556^{\star}$ Day & 0.682562 & 0.0018 & $\log \mathrm{pH}=0.632053+0.00193894^{*}$ Day & 0.677708 & 0.0020 \\
\hline Brix & Brix $=8.312+0.0901587^{*}$ Day & 0.740847 & 0.0004 & Log Brix $=0.92096+0.0042312^{*}$ Day & 0.738899 & 0.0005 \\
\hline $\mathrm{U}$ & $\mathrm{u}=465.175+18.0508^{*}$ Day & 0.754473 & 0.0003 & $\log u=2.65648+0.0148511^{*}$ Day & 0.756417 & 0.0003 \\
\hline
\end{tabular}


Table V. Arrhenius equation of pulp deterioration kinetics.

\begin{tabular}{|c|c|}
\hline Equ & $\mathbf{r}$ \\
\hline $\begin{array}{l}\log \mathbf{a}^{*}=-3.67479 \\
1058.11 * 1 / \mathrm{T}\end{array}$ & 0. \\
\hline $\begin{array}{l}\log \mathbf{b}^{*}=0.98789 \\
297.849 * 1 / \mathrm{T}\end{array}$ & - 0.910023 \\
\hline $\begin{array}{l}\log \text { brix }=1.53957 \\
446.921 * 1 / \mathrm{T}\end{array}$ & -0.937731 \\
\hline $\begin{array}{l}\log \mathbf{L}^{*}=0.906953 \\
160.945^{* 1 / T}\end{array}$ & 0.99703 \\
\hline $\begin{array}{l}\log \underset{35.1626 * 1 / \mathrm{T}}{\mathrm{pH}}=0.132489 \\
\end{array}$ & $-\overline{0.860254}$ \\
\hline $\begin{array}{l}\log u=140.973 \\
35373.8 * 1 / T\end{array}$ & - \\
\hline
\end{tabular}

The correlation coefficients of each of the equations in Table 6 indicate that the only variable that does not follow the proposed empirical model is the $a^{*}$ chromatic axis; this may be due to the fact that in the Arrhenius model there was also no correlation between the variables of temperature and $a^{*}$ chromatic axis, and the u variable, although it has a negative correlation coefficient, its value is much less than -1 , indicating a low linear correlation between temperature and time against the product's viscosity. The other variables have correlation coefficients in agreement with the empirical model, which suggests that they could be used at some point to predict the shelf-life times of the blackberry pulp at different temperatures and storage times.

The activation energies of the degradation reactions are reported in Table 6 . High activation energy can be observed for viscosity. This variable is directly related with the hydrolysis that can be encountered by the polysaccharides of high molecular weight that are in the food matrix and that cause water retention. This high value indicates the low rate that this hydrolysis process has inside the pulp [9].

The high values of activation energy indicate a high association of the process indicated with temperature, that is to say, at very high values of activation energy, the reaction will be carried out much faster at high temperatures and, therefore, at low values of activation energy the reaction will take much slower at low temperatures. This is in close agreement with the fact that all fluids by increasing their temperature rapidly decrease their viscosity, causing a much faster change [14]. Other ac tivation energy values for the study of food degradation have been reported: Remini et al. [5] reported activation energies for global color degradation $(\Delta \mathrm{E})$ in orange pulp between 49 and $99 \mathrm{~kJ} / \mathrm{mol}$; Mercali et al. [14] reported values of 71.79 and $71.94 \mathrm{~kJ} / \mathrm{mol}$ for the activation energy of the degradation reaction of anthocyanins in acerola pulp. In turn, Palazón et al., [4] published activation energy values in $\mathrm{kJ} / \mathrm{mol}$ for the color degradation of an apple compote for $\mathrm{a}^{*}$ at $13.5, b^{*}$ at 15.6 , and for $L^{*}$ at 16.4 .

Table VI. Integrated equation for the degradation kinetics of blackberry pulp.

\begin{tabular}{|c|c|c|c|c|}
\hline Variable & Qo & Ko & $\begin{array}{c}\mathrm{Ea} \\
(\mathrm{KJ} / \mathrm{mol})\end{array}$ & $\mathrm{r}$ \\
\hline $\mathrm{a}^{*}$ & 13.7390 & 0.00021145 & -8.7975497 & 0.327465 \\
\hline & & & & - \\
$\mathrm{b}^{*}$ & 8.4580 & 9.72500873 & 2.47643573 & 0.922915 \\
\hline brix & 8.2194 & 34.6393712 & 3.71587996 & 0.998524 \\
\hline $\mathrm{L} *$ & & & & - \\
\hline $\mathrm{pH}$ & 40.6701 & 8.07147675 & 1.33816111 & 0.040004 \\
\hline & & & & - \\
\hline $\mathrm{U}$ & 453.75 & $9.397 \mathrm{E}+14$ & 294.111923 & 0.282767 \\
\hline
\end{tabular}

Table 7 presents the kinetic equations for the descriptors used in the sensory analysis of blackberry pulp stored at $25^{\circ} \mathrm{C}$. The equations were obtained by performing the analyses to the final point of rejection of the appearance by the judges.

Table VII. Kinetic equations of the sensory attribu-tes of blackberry pulp stored at $25^{\circ} \mathrm{C}$

\begin{tabular}{|c|c|c|c|c|}
\hline Variables & Equation & \begin{tabular}{|l|} 
\\
Value
\end{tabular} & $\mathbf{R}$ & Order \\
\hline $\begin{array}{l}\text { Appearance } \\
\text { (App) }\end{array}$ & $\begin{array}{l}\mathrm{App}=4.5714- \\
0.1873 * \mathrm{t}\end{array}$ & 0.0000 & $\begin{array}{l}- \\
0.8225 \\
\end{array}$ & Zero \\
\hline Color (Co) & $\begin{array}{l}\mathrm{Co}=4.4761- \\
0.1746 * t\end{array}$ & 0.0000 & $\begin{array}{l}- \\
0.8385\end{array}$ & Zero \\
\hline Flavor (FI) & $\begin{array}{l}\mathrm{Fl}=4.2539- \\
0.1079 * \mathrm{t}\end{array}$ & 0.0006 & 0.7259 & Zero \\
\hline $\begin{array}{l}\text { Texture } \\
\text { (Te) }\end{array}$ & $\begin{array}{l}\text { Log te }=0.6641 \\
-0.0181 * t\end{array}$ & 0.0003 & $\begin{array}{l}- \\
0.7601\end{array}$ & First \\
\hline
\end{tabular}

It can be observed that the variables of appearance, color, and taste follow zero-order kinetics, whereas aroma and texture are modeled with first-order kinetics. It can also be observed that the aroma variable has a correlation coefficient far from -1 , which indicates the low correlation between this variable and the storage time with which it can be confirmed that aroma is slightly affected during storage and, therefore, it is not a variable to take into 
account to determine the shelf-life of the product. The variables of appearance and color are the most affected during storage, according to the sensory analysis, given that the analysis of variance shows a $p$ value of 0.000 , indicating a high significance of these parameters during storage.

Some authors have reported first-order kinetic empirical equations for sensory evaluation of color degradation in pasteurized strawberry juices for 30 days stored at $15^{\circ} \mathrm{C}$ [22] and others have evaluated the shelf-life of pasteurized orange juice by kinetic equations, reporting a product rejection time at 341 days stored at $25^{\circ} \mathrm{C}$ [23].

Figure 1 shows the evaluations carried out by the judges throughout the storage period. For appearance, texture, and color, there is statistical difference between days 12 to 15 , which is due to the viscosity and color changes detected in the physicochemical analyses, that is, the viscosity changes because increased water trapped by the

Medias y $95,0 \%$ Intervalos LSD

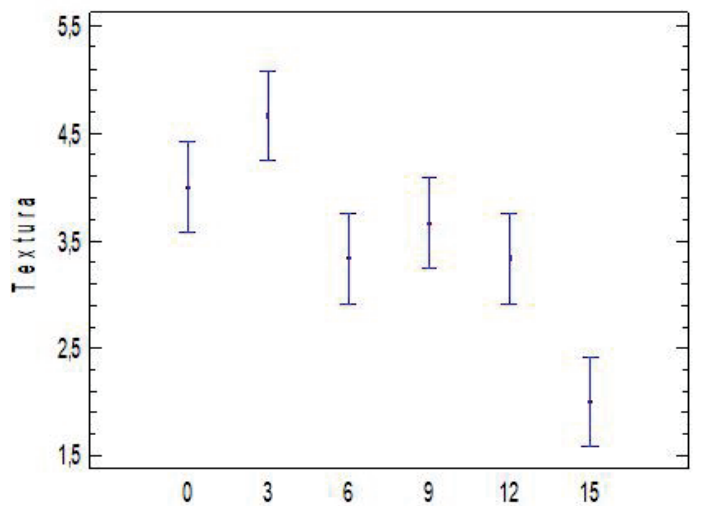

Medias y $95,0 \%$ Intervalos LSD

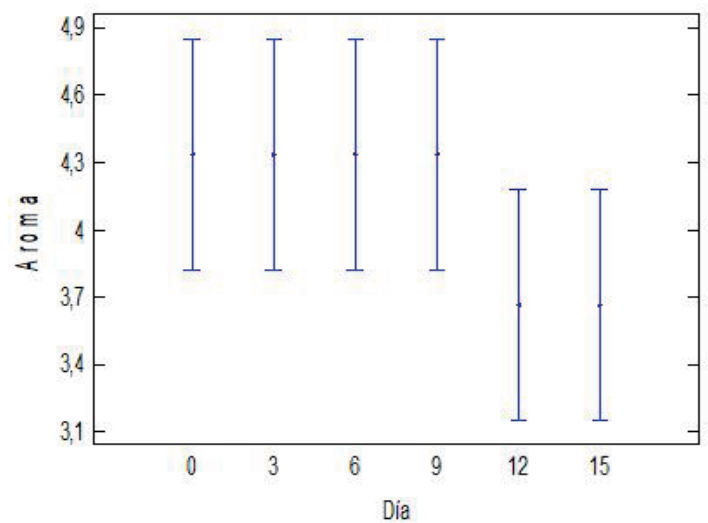

pulp polysaccharides allowed an increase in the viscosity and, therefore, an immediate detection by part of the judges in the sensory evaluation. For color, the perception of the judges goes hand in hand with the physicochemical analysis, reaffirming the degradation that anthocyanins suffer during storage by altering the a* chromatic axis and causing a change in the visual perception of the product.

For aroma, no significant differences were reported during the whole evaluation; therefore, it is not a variable to be considered during storage. Color begins to change significantly from day 9 of storage; henceforth, the judges did not assess satisfactorily the color of the samples. Taste and texture change significantly from day 12 of storage at $25^{\circ} \mathrm{C}$.

The information provided by the sensory evaluation can be corroborated because it agrees with the results obtained in the physicochemical analyses, which helps to determine the shelf-life times of the product.
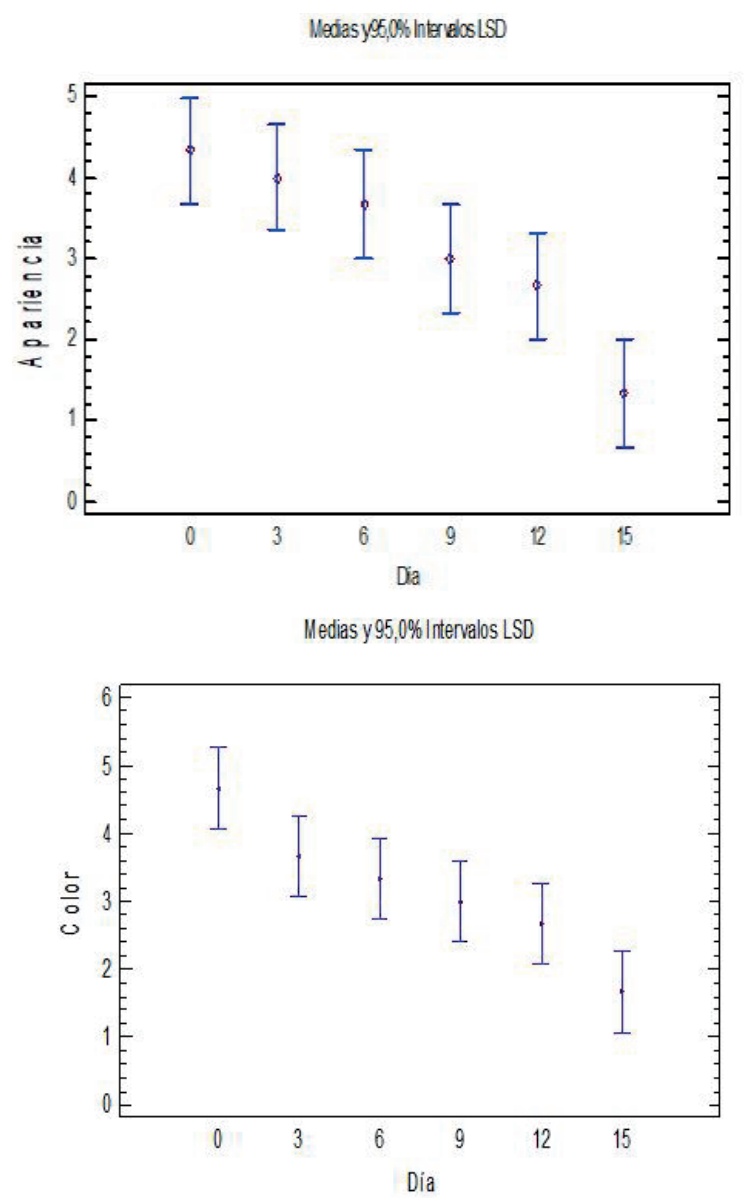
Medias y $95,0 \%$ Intervalos LSD

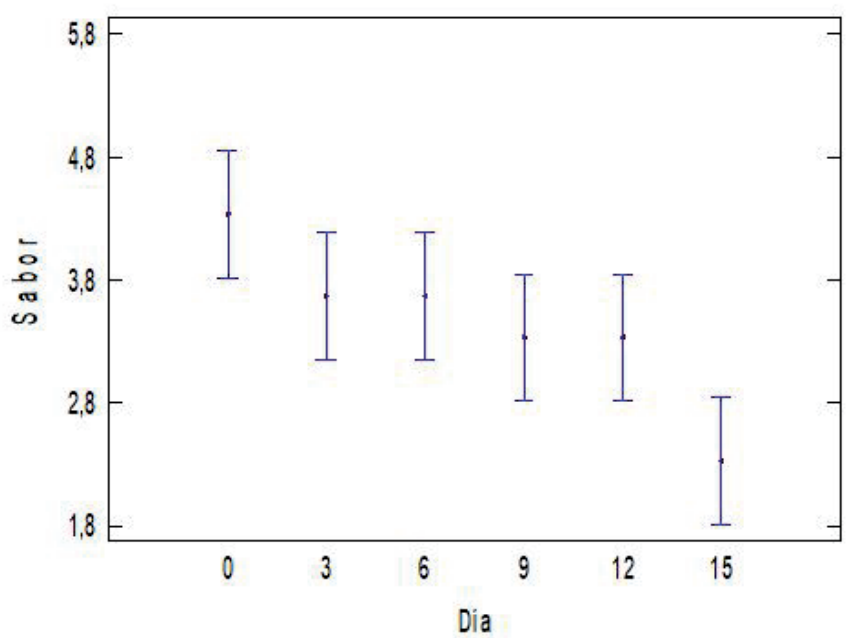

Figure 1. Sensory behavior of blackberry pulp during storage.

\section{Conclusion}

The blackberry formulation was evaluated until the detection of mesophilic microorganisms, which were detected on day 21 of storage at $15^{\circ}$ $\mathrm{C}$, at day 18 at $25^{\circ} \mathrm{C}$, and at day 11 at $35^{\circ} \mathrm{C}$. The empirical kinetic equations for the variables $\mathrm{L}^{*}$, $a^{*}, b^{*}$, brix, $\mathrm{pH}$, and viscosity were considered for each working temperature.

The parameters of the Arrhenius theoretical model were calculated for each variable and, in turn, these two equations were integrated to obtain an integrated model that represents the degradation of the blackberry pulp by integrating temperature and time within the process variables.

A sensory analysis was performed and the correlation with the physicochemical data obtained could be determined, given that the rejection times by the panelists were very close to those obtained in the physicochemical and microbiological tests.

It was possible to determine sensorily that the product was rejected on average for all descriptors at 12 days.

All the results of the sensory analysis agree faithfully with the results of the physicochemical analysis, corro borating and reaffirming the calculation of the shelf-life times determined in this work for the functional blackberry pulp.

\section{Acknowledgment}

The authors are grateful to Universidad of Quindío and, particularly, to the Vice-Rectory of Research for financing project 750 with which the results to pre-pare this paper were obtained.

\section{References}

[1] C. Escobar-Torres, "Cadena productiva de la mora, indicadores de apoyo", Ministerio de agricultura, Republica de Colombia, 2015. [online] Available in :Https://Sioc. Minagricultura.Gov.Co/Mora/Documentos

[2] Ministerio de Agricultura, Republica de Colombia, "Plataforma Siembra", 2016. [online] Available in: www.siembra.gov.co.

[3] A. Brambilla, D. Maffi and A. Rizzolo, "Study of the influence of berry-blanching on syneresis in blueberry purées", Procedia Food Science, vol. 1, pp. 1502-1508, 2011.

[4] M. Palazón, D. Pérez-Conesa, P. Abellán, G. Ros, F. Romero and M. Vidal, "Determination of shelf-life of homogenized apple-based beikost storage at different temperatures using Weibull hazard model", LWT - Food Science and Technology, vol. 42, no. 1, pp. 319-326, 2009.

[5] H. Remini, C. Mertz, A. Belbahi, N. Achir, M. Dornier and K. Madani, "Degradation kinetic modelling of ascorbic acid and colour intensity in pasteurised blood orange juice during storage", Food Chemistry, vol. 173, pp. 665-673, 2015.

[6] V. D. Quintero-Castaño, J. C. Lucas, G. Giraldo and J. Vasco, "Caracterización Fisicoquímica del mango común (Mangifera indica L.) durante 
su proceso de maduracion", Biotecnología en el Sector Agropecuario y Agroindustrial, vol. 11, no. 1, pp. 10-18, 2013.

[7] P. Martinez-Agudelo and V. Quintero-Castaño, "Evaluación fisicoquímica, microbiológica y sensorial de jugo de mora enriquecido con compuestos fisiológicamente activos. Trabajo de grado de Maestría en Química", Universidadd del Quindio, 2017.

[8] V. D. Quintero-Castaño, "Biomoléculas y Nutrición Aletheia", vol.1, no. 1, pp. 168-173, 2011.

[9] V. Quintero-Castaño and D. Navarro, "Diseño de un prototipo de jugo probiótico de mora con L. casei. Trabajo de Grado ingeniería agroindustrial", Universidad la Gran Colombia, 2010.

[10] A. Galindo, L. Noguera-Artiaga, Z. Cruz, F. Burló, F. Hernández, A. Torrecillas and Á. Carbonell-Barrachina, "Sensory and physicochemical quality attributes of jujube fruits as affected by crop load", LWT - Food Science and Technology, vol. 63, no. 2, pp. 899-905, 2015.

[11] A. Agudelo, P. Varela and S. Fiszman, "Methods for a deeper understanding of the sensory perception of fruit fillings", Food Hydrocolloids, vol. 46, pp. 160- 171, 2015.

[12] Á. T. Lemos, A. C. Ribeiro, L. G. Fidalgo, I. Delgadillo and J. Saraiva, "Extension of raw watermelon juice shelf-life up to 58 days by hyperbaric storage", Food Chemistry, vol. 231, pp. 61- 69, 2017.

[13] H. Martínez-Flores, M. Garnica-Romo, D. Bermúdez-Aguirre, P. Pokhrel and G. BarbosaCánovas, "Physico-chemical parameters, bioactive compounds and microbial quality of thermo-sonicated carrot juice during storage", Food Chemistry, vol. 172, pp. 650-656, 2015.
[14] G. Mercali, D. Jaeschke, I. Tessaro and L. Marczak, "Degradation kinetics of anthocyanins in acerola pulp: Comparison between ohmic and conventional heat treatment", Food Chemistry, vol. 136, no. 2, pp. 853-857, 2013.

[15] V. Chaves, E. Calvete and F. Reginatto, "Quality properties and antioxidant activity of seven strawberry (Fragaria x ananassa Duch) cultivars", Scientia Horticulturae, vol. 225, pp. 293-298, 2017.

[16] F. Weber and L. Larsen, "Influence of fruit juice processing on anthocyanin stability", Food Research International, vol. 100, no. 3, pp. 354-365, 2017.

[17] S. Aghajanzadeh, A. Ziaiifar and M. Kashaninejad, "Influence of thermal treatment, homogenization and xanthan gum on physicochemical properties of watermelon juice: A response surface approach", LWT Food Science and Technology, vol. 85, pp. 66-74, 2017.

[18] K. Ranjitha, D. Sudhakar, K. Shivashankara, H. Oberoi, T. Roy and H. Bharathamma, "Shelflife extension and quality retention in fresh-cut carrots coated with pectin", Innovative Food Science \& Emerging Technologies, vol. 42, pp. 91-100, 2017.

[19] F. Zienab and J. Palta, "Postharvest dip treatment with a natural lysophospholipid plus soy lecithin extended the shelf life of banana fruit", Postharvest Biology and Technology, vol. 113, pp. 58-65, 2016.

[20] V. Bosch, A. Cilla, G. García-Llatas, V. Gilabert, R. Boixand and A. Alegría, "Kinetics of ascorbic acid degradation in fruit-based infant foods during storage", Journal of Food Engineering, vol. 116, no. 2, pp. 298-303, 2013.

[21] R. Ibarz, A. Garvín and A. Ibarz, "Kinetic and thermodynamic study of the photochemical 
María Alejandra Restrepo, Julio Cesar Luna-Ramírez, Victor Dumar Quintero-Castaño

degradation of patulin", Food Research International, vol. 99, pp. 348-354, 2017.

[22] C. Buvé, B. Kebede, C. De Batselier, C. Carrillo, H. Pham, M. Hendrickx, T. Grauwet and A. Van-Loey, "Kinetics of colour changes in pasteurised strawberry juice during storage", Journal of Food Engineering, vol. 216, pp. 42-51, 2018.

[23] A. Giménez, A. Gagliardi and G. Ares, "Estimation of failure criteria in multivariate sensory shelf life testing using survival analysis", Food Research International, vol. 99, pp. 542-549, 2017. 